\title{
Response and ability of the vines of cultivar Storgozia to recover after hail damage
}

\author{
Iliyan Simeonov, Yordanka Belberova, Tatyana Yoncheva* \\ Institute of Viticulture and Enology, Pleven, Bulgaria \\ ORCID \\ Iliyan Simeonov: https://orcid.org/0000-0003-4330-9051 \\ Tatyana Yoncheva: https://orcid.org/0000-0002-8156-0530
}

\begin{tabular}{|c|c|c|}
\hline (c) (i) 구 & Article Details: & \\
\hline & Accepted: & 2021-11-18 \\
\hline & Available online: & 2021-11-30 \\
\hline
\end{tabular}

DOI: https://doi.org/10.15414/ainhlq.2021.0031

\begin{abstract}
A study was performed to determine the response and the ability to recover cultivar Storgozia after the extreme meteorological phenomenon mesocyclone registered in May 2018, accompanied by intense hail and hurricane wind. The hail damage impact on the actual fertility elements, the growing strength and the degree of shoots ripening, the yield quantitative and qualitative indicators, and the grape's chemical composition had been determined for the achieving of the objective. The study found that the damages by hail on the green parts of the vine in 2018 did not have a negative impact on the process of formation of inflorescences in the winter eyes and did not affect the vine productivity of cv. Storgozia in the following year. The damages caused by hail at the beginning of the growing season had little effect on the growing strength and the degree of shoot ripening. The leaves and leaf area $\left(1.36 \mathrm{~m}^{2}\right)$ of the main shoots are proven to be smaller in size in the year with hail, compared to the other two years, which reflects on the size of the leaves $\left(3.38 \mathrm{~m}^{2}\right)$ and leaf area of the lateral shoots, which are proven to be larger after the registered hail. The total leaf area per vine had remained almost the same in all three years, as the difference was only in the leaf area ratio of the main and lateral shoots in 2018 that did not result in disruption of the vital for the vine plant physiological and biochemical processes in the leaves. Hail had a considerable negative effect on the structure of the cluster, the berry size, the yield per vine. The overall assessment of the quality of the grapes from the three harvests shows that with varying degrees of evidence for the individual indicators, hail has a significant adverse effect on its chemical composition in terms of sugar, titratable acids, anthocyanins, and phenolic compounds.
\end{abstract}

Keywords: vine, cultivar, response, ability to recover, hail

\section{Introduction}

The increased heat in the air, higher temperatures near the earth's surface, and decreasing snow cover registered in recent years have been among the ten key indicators showing global warming (MEW, 2012; IPCC, 2013). Higher temperatures and more intense and extreme meteorological phenomena would lead to very serious negative impacts on agriculture, natural resources, human health, etc., mainly in terms of reduced crop yields and productivity and hampering the ability of the countries to produce food (Hannah et al., 2013; Koleva-Lizama, 2017; Lazoglou et al., 2017; Santos et al., 2020).

Over the last 30 years in Bulgaria there had also been a steady trend towards global warming, compared to previous periods, as well as a rise in the frequency

\footnotetext{
*Corresponding Author: Tatyana Yoncheva, Institute of Viticulture and Enology, 5800 Pleven, Bulgaria $\triangle$ tion@abv.bg
} 
of extreme meteorological and climatic phenomena (Vlaskov, 2014; Rachev and Dimitrova, 2016; Rachev and Asenova, 2017; Vlaskov, 2017).

Due to these climatic changes, in recent years the vine as a crop had increasingly been adversely affected by some unpredictable meteorological phenomena such as late spring frosts and hail storms. Hail was usually associated with spring thunderstorms, but it might occur at any time of the year. It could cause serious damage to the vineyard, not only in terms of quantity and quality of grape production but also in terms of vineyard survival and long-term development (Sioutas et al., 2007; Papagiannaki et al., 2013). Most often, hail would cause significant damage to leaves, shoots, inflorescences, clusters, and berries, but at higher intensities, it might harm also the grapevine stems and cordons (Dry, 1986).

Depending on the weather and the hail intensity, as well as the clusters' density and their location on the vine, the damage might vary from different leaf ruptures to complete defoliation of the vine and large damage to the shoots and complete loss of harvest (Fiola and De Marsay, 2013; Krstic et al., 2014; Gourieroux, 2019).

Hail, through the damage they caused to the vine plant, most often affected its total leaf area, resulting in looser and smaller size and weight clusters and lower sugar content and total phenolic reserves of grapes. At the same time, hail-damaged vines had a larger leaf area of the lateral shoots and showed a greater accumulation of total soluble solids (TSS), but no adverse effects on photosynthesis, berry mass, grape acidity, and fertility the following year (Petoumenou et al., 2019).

The recovery rate of the vine plant depended entirely on the damage intensity and was individual for each vine and vineyard. Although very often hail damage could seem extreme, vine had the unique ability to recover very successfully through the development of shoots from different vine buds (Dry, 1986).

The objective of the study was to determine the response and the ability to recover the intraspecific red wine cultivar Storgozia after the hail.

\section{Material and methodology}

\section{Plant material}

The research work was carried out in the period 2017-2019 in an experimental plantation of the intraspecific red wine cv. Storgozia (Roychev, 2012), in the Experimental base of the Institute of Viticulture and Enology (IVE) - Pleven.
The planting distance was $2.50 \times 1.30 \mathrm{~m}$, and the vines were grown on a semi-high training system with a stem height of $1 \mathrm{~m}$. The vines were spur-pruned, with a loading of 18 eyes $(9 \times 2)$ per vine.

The objective of the study was to determine the response and the ability to recover Storgozia variety grapevines after the registered on May 15, 2018, intense hail and hurricane wind. The indicators reported for the same variety in the previous year 2017 and the following one - 2019 were used as controls.

\section{Influence of hail on the vegetative and generative abilities of the cultivar}

For the implementation of the set goals and objectives, the following groups of indicators had been reported:

- To determine the impact of the damage caused by hail on the elements of actual fertility, the following indicators were recorded: ratio of developed eyes; ratio of fruit shoots; fertility rate per developed shoot and fruit shoot. The indicators characterizing the actual fertility were reported annually at the end of May for 10 vines (Katerov et al., 1990).

- To find out the effect of damage caused by hail on the vine growth strength, the maturation of the shoots was taken into account. The degree of maturation of the shoots was reported visually in late October and early November. After the shoots ripening, the following indicators were determined: average length per shoot $(\mathrm{cm})$ - total mature and green part; the average length of the mature part of the shoot $(\mathrm{cm})$; ratio of the mature part compared to the total length of the shoot; average thickness of the shoot in the $5^{\text {th }}$ internode zone $(\mathrm{mm}$ ) (Katerov et al., 1990).

- To determine the influence of damage caused by hail on some physiological processes occurring in the vine, the following indicators were reported: leaf area - the surface per leaf $\left(\mathrm{cm}^{2}\right)$, determined by linear parameters of the leaf blade and mathematical factors according to advanced Carbonneau method (Belberova and Tsvetanov, 2014; Belberova and Tsvetanov, 2017) and leaf area per vine $\left(\mathrm{m}^{2}\right)$ - determined by the defoliation per vine before harvest.

- To determine the effect of damage caused by hail on the quantitative yield indicators, it was accounted the average mass per cluster ( $\mathrm{g}$ ), the average mass per 100 berries, (g), the average yield per vine $(\mathrm{kg})$ (Katerov et al., 1990). 


\section{Chemical analysis of grapes}

To determine the effect of damage caused by hail on the qualities and chemical composition of grapes, the generally accepted methods in winemaking were used (Ivanov et al., 1979): sugars $\left(\mathrm{g} / \mathrm{dm}^{3}\right)$ - hydrometer of Dujardin; glucose and fructose $\left(\mathrm{g} / \mathrm{dm}^{3}\right)$ - iodometric method; titratable acids $\left(\mathrm{g} / \mathrm{dm}^{3}\right)$ - titration with $\mathrm{NaOH}$; tartaric and malic acid $\left(\mathrm{g} / \mathrm{dm}^{3}\right)$ - Pochinok's method; $\mathrm{pH}-\mathrm{pH}$ meter. The phenolic availability in the grape skins was also determined concerning the content of anthocyanins $\left(\mathrm{mg} / \mathrm{dm}^{3}\right)$ - method of Ribéreau-Gayon et Stonestreet and total phenolic compounds (TPC) method of Singleton and Rossi (1965).

\section{Statistical analysis}

The statistical processing of the results was performed by analysis of variance (Dimova and Marinkov, 1999).

\section{Results and discussion}

The natural disasters that have become more frequent in recent years are attracting in the increasing interest due to their great social and economic significance and the growing financial losses they have caused (Messner and Meyer, 2006; MunichRe, 2012; Papagiannaki et al., 2014). Due to the effects of climate change (such as heat waves, drought, frost, flood, wind), grape growers face problems in managing vineyards (Takahashi et al., 1976; Flexas et al., 2002; Webb et al., 2010; Morales et al. al., 2014; Mosedale et al., 2015).

Although rare, hail can cause significant damage to vineyards in a short time, having a direct impact on vine growth, grape harvest, and quality during the year with registered hail and the following year (Bora et al., 2014; Bora et al., 2016; Theodore, 2018; Staffne and Carol, 2019).

There are a number of other studies in the literature on the effect of hail damage on various crops, such as apple (Tartachnyk and Blanke, 2002), cranberry (Wells and MacManus, 2013), potato (Jalali, 2013), maize (Miya et al., 2017).

On May 15, 2018, at about 5.00 p.m., a very rare Bulgaria meteorological phenomenon called mesocyclone was registered in the region of Pleven. In its nature, that was a thunderstorm, characterized by the presence of a mesocyclone - a powerful and constantly rotating upward air current. The element was accompanied by hurricane winds (gusts of over $150 \mathrm{~km} / \mathrm{h}$ ) and intense hail (Figure 1).

A large part (over $80 \%$ ) of the main shoots are in the experimental plantation of cv. Storgozia were broken from the base or at different heights, the leaf mass was torn, most of the inflorescences were destroyed or severely damaged.

In determining the productive potential of cv. Storgozia is characterized by high fertility, which varied within narrow limits during the individual years (Table 1). In 2017 , the ratio of developed eyes (96.94\%) and fruit shoots (88.03 \%) was high but shoots with 1 cluster predominated that initiated slightly lower rates of developed shoots (1.38) and fruit shoots (1.58). In 2018, before the registration of the hail storm, the rates of the recorded indicators were high. The developed eyes per vine were almost the same as those of the previous year $(96.11 \%)$, while the fruit shoots were less $(83.03 \%)$, but the shoots with 2 clusters predominated, which gave higher fertility rates 1.81 clusters per developed shoot and 2.13 clusters per fruit shoot. After the hail and the green pruning, $87.78 \%$ of the buds developed, $53.91 \%$ of them were fruit-bearing, and the ratio of shoots with 1 and 2 clusters was almost the same. In 2019, the fertility of cv. Storgozia was very high, compared to the previous two years, which clearly showed that despite the significant damage caused by hail in 2018 on the green
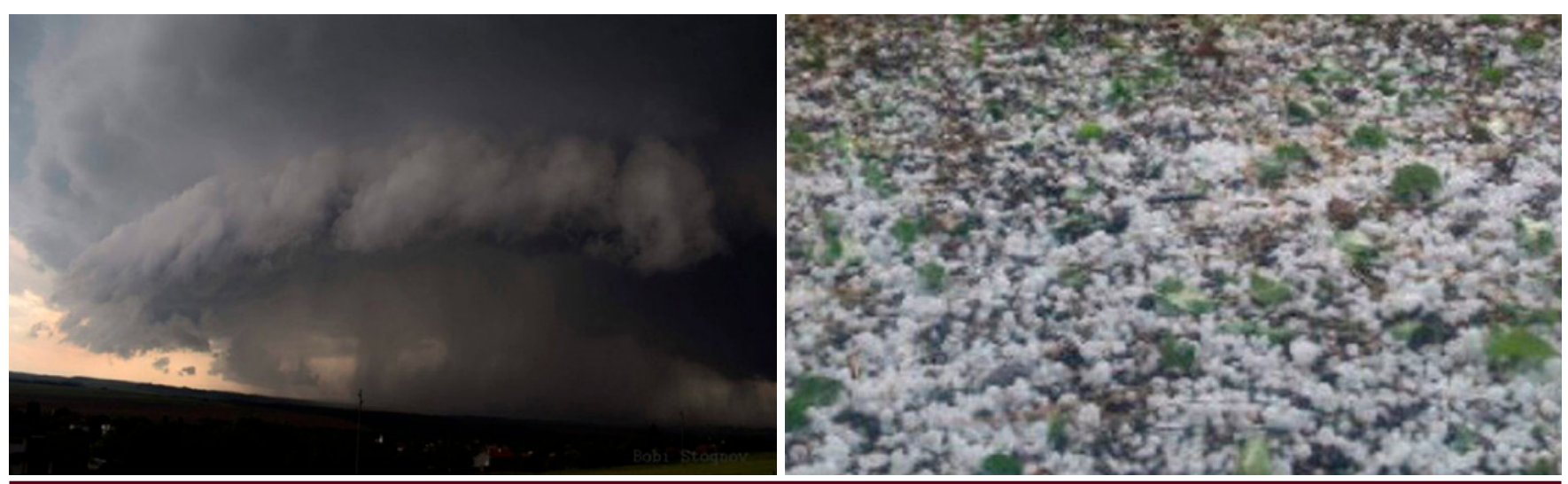

Figure 1 Mesocyclone and hail in the Pleven region (May 15, 2018) 
parts of the vine, the formation of inflorescences in the winter eyes during the same growing season occurred normally and a phenomenon of this type and during that period of vegetation did not affect the fertility of cv. Storgozia for the following year.

Table 2 presented the results determining the influence of hail and the damage caused by it on the growing strength and the degree of shoot ripening of cv. Storgozia vines. The data revealed that the extreme meteorological phenomenon of hail had a direct impact only on the indicator of average shoot length, which was smaller $(83.10 \mathrm{~cm})$ compared to the other two years of the study $(90.45 \mathrm{~cm}$ and $127.35 \mathrm{~cm})$. By the end of the vegetation season, all shoots were fully mature, accompanied by the accumulation of the maximum amount of plastic substances in their tissues that determined the vine cold resistance. There was also a significantly increased growth in the year after the hail (2019), which showed the positive recovery response of cv. Storgozia, determined by its genetically enhanced resistance to stress factors.

From the statistical analysis of the data determining the actual fertility of the vines of cv. Storgozia, it was found that in 2018, before hail, the values of the number of inflorescences per vine, the fertility rate of developed and fertility rate of fruiting shoots are higher, compared to the control year 2017, after which, with varying degrees of evidence, hail has an adverse effect on the studied productivity indicators. The high regenerative abilities of cv. Storgozia are fully manifested in 2019, when the values of all studied indicators are proven to be higher than the period after the hail in 2018 and the control year 2017, except for the number of developed vine eyes in the control period.

The results in determining the hail impact on some physiological processes occurring in the vine were similar (Table 3). When measuring the average size of the leaves of cv. Storgozia vines, it was found that after the hail the sizes of the main shoots' leaves were considerably smaller. In 2018, they were respectively 27.5 and $21.6 \%$ smaller compared to 2019 and 2017. The reduced size of the main shoots' leaves reflected the size of the lateral shoots' leaves that were larger after the hail. The average rates showed an insignificant decrease in the total size of leaf per vine after the hail, which would not have a negative impact on the course of the various physiological and biochemical processes in them.

In determining the leaf area per vine, it was found that for cv. Storgozia, in the year with the registered hail, the total leaf area was almost the same compared to both control years. The main difference was that in $2018,28.7 \%$ of it was formed by the leaves of the main shoots and $71.3 \%$ from the lateral shoots' leaves, while in both years without hail ratio was respectively 81.5 and $18.5 \%$ (2017) and 82.3 and $17.4 \%$ (2019).

Similar results were obtained by Petoumenou et al. (2019), according to which lateral shoots can provide assimilation to support their growth and send the surplus to the main shoot, which contributes to the ripening of the crop. Based on the results by Baniță et al. (2020), the natural hailstorm caused an alteration in vegetative growth grapevines due to shoot damage induced by the hailstorm.

Table 1 Actual fertility of cultivar Storgozia vines for the period 2017-2019

\begin{tabular}{|c|c|c|c|c|c|c|}
\hline Year & & $\begin{array}{l}\text { Developed eyes } \\
\text { per vine }(\%)\end{array}$ & $\begin{array}{l}\text { Fruit shoots } \\
\text { per vine (\%) }\end{array}$ & $\begin{array}{c}\text { Number of } \\
\text { inflorescences per vine }\end{array}$ & $\begin{array}{l}\text { Fertility rate per } \\
\text { developed shoot }\end{array}$ & $\begin{array}{l}\text { Fertility rate per } \\
\text { fruit shoot }\end{array}$ \\
\hline 2017 control & & 96.94 & 88.03 & 23.75 & 1.38 & 1.58 \\
\hline 2018 & before hail & 96.11 n. s & 83.03 n. s & $31.30+$ & $1.81++$ & $2.13++$ \\
\hline 2018 & after hail & 87.78 -- & 53.91 --- & $12.80---$ & $0.81---$ & $1.30--$ \\
\hline 2019 & & 95.00 n. s & $93.06+$ & $30.90+$ & $1.65+$ & $1.78+$ \\
\hline
\end{tabular}

Notes: n. s. - not significant; + significant; ++ well insured; +++ very well insured

Table 2 Growth strength and degree of shoot ripening of cultivar Storgozia in the period 2017-2019

\begin{tabular}{lccccc}
\hline Year & $\begin{array}{c}\text { Average shoot } \\
\text { length (cm) }\end{array}$ & $\begin{array}{c}\text { Average } \\
\text { internode length } \\
\text { (cm) }\end{array}$ & $\begin{array}{c}\text { Average length of } \\
\text { the shoot mature } \\
\text { part (cm) }\end{array}$ & $\begin{array}{c}\text { \% of the mature part } \\
\text { compared to the total } \\
\text { shoot length }\end{array}$ & $\begin{array}{c}\text { Average shoot } \\
\text { thickness in the 5 } \\
\text { internode zone (mm) }\end{array}$ \\
\hline $\mathbf{2 0 1 7}$ control & 90.45 & 4.96 & 89.80 & 98.75 & 5.72 \\
$\mathbf{2 0 1 8}$ & $83.10--$ & $6.25+++$ & $83.10-$ & $100.00 \mathrm{n} . \mathrm{s}$ & $6.46+$ \\
$\mathbf{2 0 1 9}$ & $127.35+++$ & $6.16+++$ & $111.25+++$ & 90.34 n. s & $7.01++$ \\
\hline
\end{tabular}

Note: n. s. - not significant; + significant; ++ well insured; +++ very well insured 
Mathematical evaluation of the data determining the strength of growth and the degree of maturation of shoots shows that hail has a proven negative impact only on the total length of shoots and the length of their mature part. With the indicators length and thickness of the internodes, the phenomenon initiates the formation of proven longer and thicker internodes of the individual shoots. The positive reaction of the vines of the studied cv. Storgozia is confirmed by the data in 2019, when for all indicators of growth and maturation of shoots, higher values are reported, compared to the control year 2017.

In determining the impact of hail damage on the quantitative and qualitative yield parameters and the chemical composition of the must, it was found that hail most clearly had a negative effect on this group of indicators (Table 4). The smaller number of inflorescences in the year 2018 with hail had a positive influence on the average mass per cluster that was higher than the other two years. The clusters were larger in size, but looser in structure. Despite the higher average mass per cluster, in 2018 the lowest average yield per vine was reported, due to the less number of clusters and the smaller berries in them.

Statistical analysis of the data shows that, as a result of the hail, the size of the main leaves and the leaf area formed by them are smaller, and those of the side shoots are larger, compared to the control. The summary indicator leaf area of 1 vine has almost the same values and the differences are unproven. The positive reaction and high recovery potential of cv. Storgozia, after hail, are confirmed by the results obtained in 2019, when all indicators of the leaf show proven positive differences compared to 2017, and in terms of leaf area, the differences between the two studied periods are minimal and mathematically unproven.

Regarding the quality characteristics of grape yield, it was found that all indicators showed a significant negative impact of hail on its chemical composition and the opportunities for the production of quality wines from the 2018 harvest. Due to the later cluster formation, the sugar content in grapes was considerably lower than in 2017 and 2019, while the acids are higher. However, glucose and fructose rates were within the

Table 3 Leaf size and leaf area of vines of the Storgozia variety for the period 2017-2019

\begin{tabular}{|c|c|c|c|c|c|c|c|}
\hline \multirow[t]{2}{*}{ Year } & \multicolumn{3}{|c|}{ Average size per leaf $(\mathrm{cm} 2)$} & \multicolumn{4}{|c|}{ Leaf area per 1 vine $(\mathrm{m} 2)$} \\
\hline & $\begin{array}{c}\text { main } \\
\text { leaves }\end{array}$ & $\begin{array}{l}\text { lateral } \\
\text { leaves }\end{array}$ & $\begin{array}{l}\text { average } \\
\text { per leaf }\end{array}$ & $\begin{array}{l}\text { main } \\
\text { leaves }\end{array}$ & $\begin{array}{l}\text { lateral } \\
\text { leaves }\end{array}$ & $\begin{array}{l}\text { total } \\
\left(\mathrm{cm}^{2}\right)\end{array}$ & $\begin{array}{l}\text { leaf area } \\
\text { per vine }\end{array}$ \\
\hline 2017 control & 76.20 & 25.50 & 50.85 & 38698.10 & 8752.54 & 47450.64 & 4.75 \\
\hline 2018 & 59.75--- & $33.53++$ & 46.64- & 13 639.80--- & $33799.12+++$ & 47438.94 n.s & 4.74 n. s \\
\hline 2019 & $82.40+$ & $30.11+$ & $56.26+$ & 37228.68 n. s & $7863.58-$ & 45092.26 n.s & 4.51 n. s \\
\hline
\end{tabular}

Notes: n. s. - not significant; + significant; ++ well insured; +++ very well insured

Table 4 Quantitative and qualitative characteristics of grape yield from cultivar Storgozia for the period 2017-2019

\begin{tabular}{|c|c|c|c|}
\hline \multirow[t]{2}{*}{ Indicators } & \multicolumn{3}{|c|}{ Year } \\
\hline & 2017 control & 2018 & 2019 \\
\hline Average yield per vine (kg) & 3.450 & $2.667--$ & $4.606+++$ \\
\hline Average mass per cluster (g) & 145.14 & $169.43+$ & 140.92 n.s \\
\hline Average mass per 100 berries (g) & 212.06 & $182.31--$ & $188.46-$ \\
\hline Sugars $\left(\mathrm{g} / \mathrm{dm}^{3}\right)$ & 237.00 & $204.00---$ & $234.00 \mathrm{n.s}$ \\
\hline Titratable acids $\left(\mathrm{g} / \mathrm{dm}^{3}\right)$ & 5.88 & $6.62++$ & 5.39 n.s \\
\hline Tartaric acid $\left(\mathrm{g} / \mathrm{dm}^{3}\right)$ & 2.54 & $4.61+++$ & $1.05--$ \\
\hline Malic acid $\left(\mathrm{g} / \mathrm{dm}^{3}\right)$ & 4.20 & $4.99+$ & 4.20 n. s \\
\hline Glucose $\left(\mathrm{g} / \mathrm{dm}^{3}\right)$ & 96.30 & $72.00---$ & $103.50 \mathrm{n.s}$ \\
\hline Fructose $\left(\mathrm{g} / \mathrm{dm}^{3}\right)$ & 147.70 & $132.00-$ & 130.50 n.s \\
\hline pH & 3.43 & 3.58 n. s & 3.50 n.s \\
\hline Anthocyanins in skins $\left(\mathrm{mg} / \mathrm{dm}^{3}\right)$ & 439.48 & $285.65---$ & $473.46+$ \\
\hline TPC $\left(\mathrm{g} / \mathrm{dm}^{3}\right)$ & 0.85 & $0.38---$ & 0.90 n.s \\
\hline
\end{tabular}

Notes: n. s. - not significant; + significant; ++ well insured; +++ very well insured 
normal ranges with a predominance of fructose, which was observed in all three years. The anthocyanins and TPC content in the grape skins from 2018 were significantly lower, respectively $285.65 \mathrm{mg} / \mathrm{dm}^{3}$ and $0.38 \mathrm{~g} / \mathrm{dm}^{3}$. Their quantity was almost twice less than their content in the grapes from 2017 and 2019 harvests. The negative impact of hail on the analysed indicators, however, was completely overcome by cv. Storgozia the following year and the vintage had a chemical composition, without deviations from the variety typical specification.

Statistical analysis of the data determining the quantitative indicators of yield shows that hail has a proven negative effect on grain mass and yield of 1 vine. Due to the smaller number of bunches, their mass is proven to be higher than in 2017. In 2019, the mass of 1 bunch is approximately the same as in 2017, but most of the formed inflorescences initiate a higher yield of grapes and smaller grains in the bunches compared to the control period.

The results of the analysis of the quality of obtained grapes confirm the significant negative impact of the hail phenomenon established so far. In all examined indicators, with different degrees of evidence, compared to the control year 2017, lower (sugars, anthocyanins, TPC) or higher values (acids) are reported, which determine the quality of the obtained raw material from grapes as unsatisfactory. In 2019, the quality of the obtained grapes of the cv. Storgozia is identical to that in 2017 (control), which shows the high recovery potential of the studied variety after the hail.

From the above data, it could be argued that with the hail, registered at the beginning of the growing season, the yield and its quality from cv. Storgozia were significantly reduced, however the obtained grapes had satisfactory quantity and quality, minimizing the losses from this extreme meteorological phenomenon.

\section{Conclusions}

The damages caused by hail on the green parts of the vine in 2018 did not have a negative impact on the process of formation of inflorescences in the winter eyes and did not affect the vine productivity of cv. Storgozia in the following year. The damages caused by hail at the beginning of the growing season had little effect on the growing strength and the degree of shoot ripening. The leaves and leaf area of the main shoots are proven to be smaller in size in the year with hail, compared to the other two years, which reflects on the size of the leaves and leaf area of the lateral shoots, which are proven to be larger after the registered hail. The total leaf area per vine had remained almost the same in all three years, as the difference was only in the leaf area ratio of the main and lateral shoots in 2018 that did not result in disruption of the vital for the vine plant physiological and biochemical processes in the leaves. Hail had a considerable negative effect on the structure of the cluster, the berry size, the yield per vine. The overall assessment of the quality of the grapes from the three harvests shows that with varying degrees of evidence for the individual indicators, hail has a significant adverse effect on its chemical composition in terms of sugar, titratable acids, anthocyanins, and phenolic compounds.

\section{Conflicts of interest}

The authors declare no conflict of interest.

\section{Ethical statement}

This article does not contain any studies that would require an ethical statement.

\section{References}

Banita, S., Sestras, A., Olteanu, I., Calugar, A., \& Bunea, C.I. (2020). The influence of hail and treatments with amino-acids on the fertility and biologic balance of grapevines. Romanian Journal Horticulture, I, 111-118. https://doi.org/10.51258/RJH.2020.15

Belberova, Y., \& Tsvetanov, E. (2014). Teoretichni krivi za opredelyane na listnata povŭrkhnost pri lozi ot sort Misket Kallashki (Theoretical curves for determining the leaf surface in vines of the cv. Misket Kailashki). Lozarstvo i Vinarstvo, 6, 8-12. (in Bulgarian)

Belberova, Y., \& Tsvetanov, E. (2017). Regression curves for determining the leaf surface in vines of the cultivar Storgozia. Journal of Mountain Agriculture on the Balkans, 20(3), 333-342.

Bora, F.D., Dina, I., Iliescu, M., Zaldea, G., \& Guta, I.C. (2016). Analysis and evaluation of the main ecoclimatic conditions from Romanian Vineyards. Bulletin UASVM Horticulture, 73(2), 221-223. https://doi.org/10.15835/buasvmcn-hort:12122

Bora, F.D., Pop, T.I., Bunea, C.I., Urcan, D.E., Babes, A., MihalyCozmuta, L., Mihaly-Cozmuta, A., \& Pop, N. (2014). Influence of ecoclimatic and ecopedological conditions on quality of white wine grape cultivars from North-West of Romania. Bulletin UASVM Horticulture, 71(2), 218225. https://doi.org/10.15835/buasvmcnhort:10545

Dimova, D., \& Marinkov, E. (1999). Eksperimentalni raboti i biometriya (Experimental works and biometry). Academic Publ. House of HAI, Plovdiv. (in Bulgarian).

Dry, P. (1986). The effects of hail damage may carry over to next season. Australian Grapegrower Winemaker, 275, 22-24. 
Fiola, J., \& De Marsay, A. (2013). Hail damage. Timely Viticulture. Western Maryland Research and Education Center, Keedysville, MD, 1-2.

Flexas, J., Bota, J., Escalona, J.M., Sampol, B., \& Medrano, H. (2002). Effects of drought on photosynthesis in grapevines under field conditions: An evaluation of stomatal and mesophyll limitations. Functional Plant Biology, 29(4), 461-471. https://doi.org/10.1071/ PP01119

Gourieroux, A. (2019). Hail and severe storms. Grapevine Management Guide 2019-20, 36-38. https://www.dpi. nsw.gov.au/data/assets/pdf file/0004/1158313/ Hail-and-severe-storms.pdf.

Hannah, L., Roehrdanz, P., Ikegami, M., Shepard, A., Shaw. M., Tabor, G., Zhi, L., Marquet, P., \& Hijmans, R. (2013). Climate change, wine, and conservation. Proceedings of the Natural Academy of Science of the USA, 110(17), 69076912. http://doi.org/10.1073/pnas.1210127110.

IPCC Intergoverment Panel On Climate Change (2013). Climate Change 2013. The Physical Science Basis, https://www.klimamanifest-von-heiligenroth.de/wp/ wp-content/uploads/2016/06/IPCC 2013 WG1AR5 S916 S917 Extremwetter Zitate mitTitelCover.pdf.

Ivanov, T., Gerov, S., Yankov, A., Bambalov, G., Tonchev, T., Nachkov, D., \& Marinov, M. (1979). Praktikum po tehnologiya na vinoto (Practicum in wine technology). Publ. House Hristo G. Danov, Plovdiv. (in Bulgarian).

Jalali, A.H. (2013). Potato (Solanum tuberosum L.) yield response to simulated hail damage. Archives of Agronomy and Soil Science, 59(7), 981-987. https://doi. org/10.1080/03650340.2012.699674

Katerov, K. (1990). Bulgarska ampelografiya, 1 (Bulgarian Ampelography, 1), Bulgarian Academy of Sciences, Sofia (in Bulgarian)

Koleva-Lizama, I. (2017). Otsenka na vazdeistvieto na izmenenieto na klimata varhu selskoto stopanstvo (Climate change impact assessment on agriculture). Management and Sustainable Development, 66(5), 3540. (in Bulgarian)

Krstic, M., Essling, M., \& Singh, L. (2014). Managing grapevines post hail damage. Murray Valley Wine Growers Factsheet. https://www.mvwi.com.au/fact-sheets/hail/ managing-grapevines-post-hail-damage/.

Lazoglou, G., Anagnostopoulou, C., \& Koundouras, S. (2017). Climate change projections for Greek viticulture as simulated by a regional climate model. Theoretical and Applied Climatology, 133(33), 551-567. http://doi. org/10.1007/s00704-017-2198-2.

Messner, F., \& Meyer, V. (2006). Flood damage, vulnerability and risk perception - challenges for flood damage research, Proceedings of the NATO Advanced Research on Flood Risk Management - Hazards, Vulnerability and Mitigation Measures. Springer Editions, 2006.

Ministry of Environment and Water (MEW). (2012). Treti natsionalen plan za deistvie po izmenenie na klimata za perioda 2013-2020 (Third national plan for action for climate change for the period 2013-2020). http://
www3.moew.government.bg/files/file/Climate/ Climate_Change_Policy_Directorate/Treti_nacionalen plan za deistvie po izmenenie na klimata.pdf (in Bulgarian)

Miya, S.P., Modi, A.T., \& Mabhaudhi, T. (2017). Interactive effects of simulated hail damage and plant density on maize seed quality. Seed Science and Technology, 45(1), 100-111. https://doi.org/10.15258/sst.2017.45.1.02

Morales, M., Toro, G., Riquelme, A., Selles, G., Pinto, M., \& Ferreyra, R. (2014). Effect of different rootstocks on photosynthesis and nutritional response of grapevines cultivar 'Sultanina' under flooding stress. Acta Horticulturae, 1045, 123-131. https://doi. org/10.17660/ActaHortic.2014.1045.16

Mosedale, J.R., Wilson, R.J., \& Maclean, I.M.D. (2015). Climate change and crop exposure to adverse weather: changes to frost risk and grapevine flowering conditions. PLoS ONE, 10(10), e0141218. https://doi.org/10.1371/ journal.pone.0141218

Munichre: available at:http://www.munichre.com/touch/ naturalhazards/en/natcatservice/default.aspx (last access:November 2012), 2012.

Papagiannaki, K., Lagouvardos, K., \& Kotroni, V. (2013). A database of high-impact weather events in Greece: A descriptive impact analysis for the period 2001-2011. Natural Hazards Earth Systems Science, 13(3), 727-736. https://doi.org/10.5194/nhess-13-727-2013.

Papagiannaki, K., Lagouvardos, K., Kotroni, V., \& Papagiannakis, G. (2014). Agricultural losses related to frost events: Use of the $850 \mathrm{hPa}$ level temperature as an explanatory variable of the damage cost. Natural Hazards and Earth System Sciences, 14(9), 2375-2386. https://doi.org/10.5194/nhess-14-2375-2014

Petoumenou, D., Biniari, K., Xyrafis, E., Mavronasios, D., Daskalakis, I., \& Palliotti, A. (2019). Effects of natural hail on the growth, physiological characteristics, yield, and quality of Vitis vinifera L. cv. Thompson Seedless under Mediterranean growing conditions. Agronomy, 9(4), 197. https://doi.org/10.3390/agronomy9040197.

Rachev, G., \& Asenova, N. (2017). Aktualni promeni na temperaturata na vazduha i valejite $\mathrm{v}$ Bulgaria (Current changes of the air temperature and precipitation in Bulgaria). Annual of Sofia University "St. Kliment Ohridski", Faculty of Geology and Geography, 110(2), 7-24. (in Bulgarian)

Rachev, N., \& Dimitrova, D. (2016). Promeni v srednite temperaturi i valejite v Bulgaria za perioda 1995-2012 (Changes in average temperatures and precipitation in Bulgaria for the period 1995-2012). Annual of Sofia University "St. Kliment Ohridski", Faculty of Physics, 109, 1-25. (in Bulgarian)

Roychev, V. (2012). Ampelografiya (Ampelography). Academic Publishing House of Agricultural University, Plovdiv. (in Bulgarian).

Santos, J., Fraga, H., Malheiro, A., Moutinho-Pereira, J., Dinis, L., Correia, C., Moriondo, M., Leonini, L., Dibari, C., Costafreda-Aumedes, S., Kartschall, T., Menz, C., Molitor, 
D., Junk, J., Beyer, M., \& Schultz, H. (2020). A review of the potential climate change impacts and adaptation options for European viticulture. Applied Sciences 10(9), 3092. https://doi.org/10.3390/app10093092.

Singleton, V.L., \& Rossi J.A. (1965). Colorimetry of total phenolics with phosphomolybdic phosphotungstic acid reagents. American Journal of Enology and Viticulture, 16, 144-158.

Sioutas, M., Meaden, G., \& Webb, J. (2007). Hail frequency distribution and intensity in Northern Greece. Atmospheric Research, 93(1), 526-533. https://doi. org/10.1016/j.atmosres.2008.09.023

Staffne, E.T., \& Carroll, B.L. (2019). Simulated abiotic injury alters yields of southern interspecific hybrid grape cultivars. Horticulturae, 5(2), 44. https://doi. org/10.3390/horticulturae5020044

Takahashi, K., Kuranaka, M., \& Miyagava, A. (1976). The effects of wind on grapevine growth: Windbreaks for vineyards. Bulletin of the Shimane Agricultural Experiment Station, 14, 39-83.

Tartachnyk, I., \& Blanke, M. (2002). Efect of mechanicallyhail simulated on photosynthesis, dark respiration and transpiration of apple leaves. Environmental and Experimental Botany, 48(2), 169-175. https://doi. org/10.1016/S0098-8472(02)00022-9

Teodor, L. (2018). Muntean considerations regarding the use of anti-hail nets for the protection of table grape plantations in Hinova viticultural area, Mehedinti County. Scientific Papers.Series B, Horticulture. LXII, 227-330.
Vlaskov, V. (2014). Ekstremni temperaturi v savremenniya klimat na Bulgaria - razvitie i prognozi (Extreme temperatures in the modern climate of Bulgaria development and forecasts). Yearbook of the Association of Anthropology, Ethnology and Folklore "Ongle", 420432. (in Bulgarian)

Vlaskov, V. (2017). Tropicheski noshti v Bulgaria (19972016) (Tropical nights in Bulgaria (1997-2016)). Management and sustainable development, 66(5), 4144. (in Bulgarian)

Webb, L., Whiting, J., Watt, A., Hill, T., Wigg, F. Dunn, G., Needs, S., \& Barlow, E.W.R. (2010). Managing grapevines through severe heat: A survey of growers after the 2009 summer heatwave in south-eastern. Australian Journal of Wine Research, 21(2-3), 147-165. https://doi.org/1 $\underline{0.1080 / 09571264.2010 .530106}$

Wells, L.D., \& Macmanus, P.S. (2013). Efects of simulated hail events and subsequent fungicide applications on cranberry fruit rot incidence and yield. Plant Disease, 97(9), 1207-1211. https://doi.org/10.1094/ PDIS-01-13-0052-RE 